\title{
Economics of Growing Tea Organically in the Initial Years in Terai Zone of West Bengal Condition
}

\author{
Vannam Yugandhar $^{1^{*}}$, G. Chandrashekhar ${ }^{2}$ and H. Bhattacharjee ${ }^{3}$ \\ ${ }^{1}$ Dr.Y.S.R. Horticultural University, Krishi Vigyan Kendra, Vonipenta, Mydukur, Dr YSR \\ Kadapa District- 516173, Andhra Pradesh, India \\ ${ }^{2}$ Department of Spices and Plantation Crops, Faculty of Horticulture, Bidhan Chandra Krishi \\ Viswavidyalaya, Mohanpur, Nadia, 741252, West Bengal, India \\ ${ }^{3}$ Department of Plantation Crops and Processing, Uttar Banga Krishi Viswavidyalaya \\ Pundibari, Coochbehar - 736165, West Bengal, India \\ *Corresponding author
}

A B S T R A C T

In tea during last 50 years, considerable increase in production, productivity and quality of tea achieved because of using various chemical inputs like fertilizers and plant protection chemicals. However, indiscriminate use of chemical inputs degraded soil health and product quality and the environment. Organically produced tea without any hazardous

Keywords

Tea, Organic, Planting time, B: C ratio

Article Info

Accepted:

04 April 2018

Available Online:

10 May 2018 chemicals and residues are better in quality and fetches premium price, make a perfect health drink. Organic tea cultivation is gaining momentum. The feasibility of organic cultivation depends right from planting though recommended dose for organic tea cultivation, particularly for terai region, is not there. So, the present investigation was carried out from 2015 to 2017 and to evaluate the economics of growing tea organically in the initial years among various treatments were $-\mathrm{T}_{1}$ : Control (without any organic matter and inorganic fertilizer); $\mathrm{T}_{2}$ : Conventional (NPK @ recommended doses); $\mathrm{T}_{3}$ : Vermicompost @ $1.0 \mathrm{~kg} ; \mathrm{T}_{4}$ : Vermicompost @ $1.0 \mathrm{~kg}+$ (Azotobacter + PSB + Fl.pseudomonas + Azospirillum) each @ $5.0 \mathrm{~g} / \mathrm{plant}$; $\mathrm{T}_{8:}$ FYM @ $2.5 \mathrm{~kg}$ (Azotobacter + VAM + Fl.pseudomonas + Azospirillum) each@ $5.0 \mathrm{~g} / \mathrm{plant}$, replicated thrice and laid out in completely randomized block design. The Evaluation of economics including fixed costs and variable costs among the organic treatments $\mathrm{T}_{4}$ was observed to be the best with an income per ha for two years was Rs. 67,876 followed by $T_{5}$ with Rs. 61,862 per ha. So, from the investigation, by observing the young tea plants only for two years, though it is premature to conclude, it was observed that $\mathrm{T}_{4}$ was the most remunerative treatment of organics for Terai zone of West Bengal.

\section{Introduction}

Tea is the second most popular drink in the world after water (Van der Wal, 2008). It is made from young tender leaves and unopened buds of the evergreen tea plant (Camellia sinensis (L.) O. Kuntze), belonging to the family Theaceae. Over the last 20 years, India's world ranking as an exporter of tea has come down from number one to number four, 
in the face of stiff competition from Sri Lanka, Kenya, and China (Majumdar et al., 2012). Recent trends showed drastic reduction in tea exports from India, as the importing countries preferred residue free and superior quality tea. Only about one per cent of total tea produced in India was organic tea.

Application of chemical fertilizer as such without conservation of soil fertility, not only results in depletion of soil nutrient reserves but also disrupt the biological eco balance of soil - plant system, product quality and the environment. Tea is grown mainly for young tender apical two leaves and a bud, so, quality is very crucial with regard to human health. Organically produced tea without any hazardous chemicals and residues is better in quality and fetches premium price - about 30 to $40 \%$ more than conventionally grown teas. Organically produced teas have longer shelflife, better keeping quality, higher antioxidant activity and make them a perfect health drink (Parmar, 2008). Organic tea cultivation is gaining momentum and many tea plantations in the world including India are transforming to organic, conversion of traditional estate to organic estate is a complex operation involving risk and problems. A minimum of three years is needed for an established conventional garden to be converted to organic, which has to be certified by a certifying agency. The feasibility of organic tea cultivation depends right from the initial years after planting, maintaining health and vigour, development of a good frame, proper nutrition and protection from pests and diseases are utmost necessary (Barthakur, 2004, Phukan et al., 2011). Organic manures and Biofertilizers are main source of plant nutrition in organic farming due to its multiple functions in soil (Mamaril et al., 1986). Various organic amendments are crop residues, vermicompost, farm yard manure and green manure. Uses of these inputs are increasingly becoming important aspects of environmentally sound sustainable agriculture (Timsina and Connor, 2001). The use of biofertilizers and organic manure offer a great opportunity to increase the crop productivity with less cost. Therefore, inputs chosen for better establishment of young tea plants also play key role to guarantee the desired crop performance and economic returns to the farmers but in organic tea culture (Singh et al., 2011). West Bengal, particularly Darjeeling is known all over the world for producing the best quality tea. Reports on systematic field experiments on integrated supply of nutrients through organic and bio-fertilizers are scanty and recommended dose for organic cultural practices is lacking, in West Bengal particularly for Terai zone, keeping this in view the present investigation was conducted.

\section{Materials and Methods}

The experiment was carried out form March, 2015 to May, 2017 at the Instructional Plots of the Department of Plantation Crops and Processing, Uttar Banga Krishi Viswavidyalaya, Pundibari, Cooch Behar, West Bengal, India. To evaluate the economics of growing tea organically in the initial years costs of all costs fixed and variable costs of the items were takenPlanting materials, land preparation, digging drains etc., digging pits and planting, application of organic manures, chemical fertilizers, rock phosphate, neem cake and biofertilizers, bringing up of young tea plants, irrigation, weed management, mulching, pests and disease management harvesting, etc.

\section{Results and Discussion}

\section{Economics of growing young tea under organic cultivation}

Various operations done from field preparation to harvesting have been listed in Table 1 under two broad groups - fixed costs 
and variable costs. Treatment wise costs involved, yield of green leaf and income could have generated at the prevalent market price have been presented in Table 2 .

It is evident from Table 2 that minimum cost per plot of Rs. 814.31 was involved in $\mathrm{T}_{1}$ (control), while maximum cost of Rs. 978.31 was incurred in $\mathrm{T}_{4}, \mathrm{~T}_{5}, \mathrm{~T}_{7}$, and $\mathrm{T}_{8}$. When converted to per ha, there was an involvement of a minimum of Rs. 5,16,366.51 in $\mathrm{T}_{1}$ (control) to a maximum of Rs. 6,20,361.44 in $\mathrm{T}_{4}, \mathrm{~T}_{5}, \mathrm{~T}_{7}$, and $\mathrm{T}_{8}$. Green leaf yield per plot during the whole period of experimentation, i.e. up to two years ranged from $0.91 \mathrm{~kg}\left(\mathrm{~T}_{1}\right)$ to $2.15 \mathrm{~kg}\left(\mathrm{~T}_{4}\right)$, which were equivalent to $571.94 \mathrm{~kg} / \mathrm{ha}$ and $1,357.52 \mathrm{~kg} / \mathrm{ha}$ respectively.
Considering the price of organic green leaf @ Rs. 50.00 per kg and conventional leaf @ Rs. 20.00 per $\mathrm{kg}$, income generated could have been minimum Rs. 40.40 per plot in $T_{2}$, and maximum Rs. 107.50 in $\left(\mathrm{T}_{4}\right)$.

Corresponding income per ha for two years were calculated to be from Rs. 25,498.60 in $\mathrm{T}_{2}$ to Rs. $67,876.00$ in $\mathrm{T}_{4}$ respectively. Over all, in $\mathrm{T}_{1}$ (control) total cost of cultivation Rs. 5,16,366.51 per ha, income Rs. 28,597.00 per ha, loss of Rs. 4,87,769.51 per ha. Among the organic plots $\mathrm{T}_{3}$ and $\mathrm{T}_{6}$ involved a total cost of cultivation Rs. 5,79,778.06 per ha, income generated Rs. 46,130.50 and Rs. 39,484.00 per ha respectively.

Table.1 Various costs involved of growing tea organically in the initial years

\begin{tabular}{l} 
1. Land preparation \\
\hline a. Tractor ploughing \\
\hline b. Power tiller ploughing \\
\hline c. Cleaning of weeds and stubles \\
\hline d. Layout of the field \\
\hline 2.Planting materials \\
\hline 3. Digging drains \\
\hline 4.Digging pits and planting \\
\hline 5. Intercultural operations \\
\hline a. Bringing up of young tea \\
\hline b. Weeding \\
\hline c. Mulching \\
\hline d. Application of organic manures, biofertilizers and fertilizers \\
\hline e. Pests and disease management \\
\hline f. Irrigation \\
\hline g. Harvesting \\
\hline 1. Organic manures \\
\hline a. FYM \\
\hline b. Vermi compost \\
\hline 2. Biofertilizers \\
\hline 3. Fertilizers \\
\hline Urea, SSP, MOP \\
\hline 4. Plant protection \\
\hline
\end{tabular}


Table. 2 Evaluation of costs involved and income generated from organic cultivation of tea for two initial years

\begin{tabular}{|c|c|c|c|c|c|c|}
\hline Treatments & $\begin{array}{c}\text { Cost of } \\
\text { cultivation/plot } \\
\text { (Rs.) }\end{array}$ & $\begin{array}{l}\text { Cost of } \\
\text { cultivation/ha } \\
\text { (Rs.) }\end{array}$ & $\begin{array}{c}\text { Green } \\
\text { leaf } \\
\text { yield } \\
\text { (kg/plot) }\end{array}$ & $\begin{array}{c}\text { Green } \\
\text { leaf } \\
\text { yield } \\
\text { (kg/ } \\
\text { ha) }\end{array}$ & $\begin{array}{c}\text { Income } \\
\text { per plot } \\
*(\mathrm{Rs} .) \\
\text { @50/kg) }\end{array}$ & $\begin{array}{c}\text { Income } \\
\text { per ha* } \\
(\text { Rs.) } \\
\text { @50/kg) }\end{array}$ \\
\hline $\mathrm{T}_{1}$ (Control) & 814.31 & $5,16,366.51$ & 0.91 & 571.94 & 45.50 & $28,597.00$ \\
\hline $\mathrm{T}_{2}$ (Conventional) & 817.22 & $5,18,211.79$ & 2.02 & 1274.93 & 40.40 & $25,498.60$ \\
\hline $\mathrm{T}_{\mathbf{3}}(\mathrm{VC})$ & 914.31 & $5,79,778.06$ & 1.46 & 922.61 & 73.00 & $46,130.50$ \\
\hline $\mathrm{T}_{4}(\mathrm{VC}+\mathrm{Az}+\mathrm{P}+\mathrm{Pf}+\mathrm{As})^{*}$ & 978.31 & $6,20,361.44$ & 2.15 & 1357.52 & 107.50 & $67,876.00$ \\
\hline $\mathrm{T}_{\mathbf{5}}(\mathrm{VC}+\mathrm{Az}+\mathrm{V}+\mathrm{Pf}+\mathrm{As})^{* * * *}$ & 978.31 & $6,20,361.44$ & 1.96 & 1237.25 & 98.00 & $61,862.50$ \\
\hline $\mathrm{T}_{6}(\mathrm{FYM})$ & 914.31 & $5,79,778.06$ & 1.25 & 789.68 & 62.50 & $39,484.00$ \\
\hline $\mathrm{T}_{7}(\mathrm{FYM}+\mathrm{Az}+\mathrm{P}+\mathrm{Pf}+\mathrm{As}) *$ & 978.31 & $6,20,361.44$ & 1.77 & 1122.16 & 88.50 & $56,108.00$ \\
\hline $\mathrm{T}_{8}(\mathrm{FYM}+\mathbf{A z}+\mathrm{V}+\mathrm{Pf}+\mathbf{A s})^{* * *}$ & 978.31 & $6,20,361.44$ & 1.61 & 1017.27 & 80.50 & $50,863.50$ \\
\hline
\end{tabular}

*Sell price of green leaf organic tea cost Rs.50 and conventional cost Rs. 20 per kg

Table.3 Total cost of cultivation, income generated and profit/loss earned from organic cultivation of tea during intial years

\begin{tabular}{|c|c|c|c|c|}
\hline Treatments & $\begin{array}{l}\text { Total Cost of } \\
\text { cultivation } \\
\text { (Rs /ha) }\end{array}$ & $\begin{array}{c}\text { Green leaf } \\
\text { yield } \\
\text { (kg/ ha) }\end{array}$ & $\begin{array}{c}\text { Total } \\
\text { income } \\
(\mathbf{R s}) \\
\text { (@50/kg) }\end{array}$ & Profit/Loss \\
\hline $\mathrm{T}_{1}$ (Control) & $5,16,366.51$ & 571.94 & $28,597.00$ & $(-) 4,87,769.51$ \\
\hline $\mathbf{T}_{2}$ (Conventional) & $5,18,211.79$ & 1274.93 & $25,498.60$ & $(-) 4,92,713.19$ \\
\hline $\mathrm{T}_{\mathbf{3}}(\mathrm{VC})$ & $5,79,778.06$ & 922.61 & $46,130.50$ & $(-) 5,33,647.56$ \\
\hline $\mathrm{T}_{4}(\mathrm{VC}+\mathrm{Az}+\mathrm{P}+\mathrm{Pf}+\mathrm{As})^{*}$ & $6,20,361.44$ & 1357.52 & $67,876.00$ & $(-) 5,52,485.44$ \\
\hline $\mathrm{T}_{5}(\mathrm{VC}+\mathrm{Az}+\mathrm{V}+\mathrm{Pf}+\mathrm{As}) * *$ & $6,20,361.44$ & 1237.25 & $61,862.50$ & $(-) 5,58,498.94$ \\
\hline $\mathrm{T}_{6}(\mathrm{FYM})$ & $5,79,778.06$ & 789.68 & $39,484.00$ & $(-) 5,40,294.06$ \\
\hline $\mathrm{T}_{7}(\mathrm{FYM}+\mathrm{Az}+\mathrm{P}+\mathrm{Pf}+\mathrm{As}) *$ & $6,20,361.44$ & 1122.16 & $56,108.00$ & $(-) 5,64,253.44$ \\
\hline $\mathrm{T}_{8}(\mathrm{FYM}+\mathrm{Az}+\mathrm{V}+\mathrm{Pf}+\mathrm{As})^{* * *}$ & $6,20,361.44$ & 1017.27 & $50,863.50$ & $(-) 5,69,497.94$ \\
\hline
\end{tabular}

$\mathrm{T}_{4}, \mathrm{~T}_{5}, \mathrm{~T}_{7}$ and $\mathrm{T}_{8}$ total cost of cultivation Rs. $6,20,361.44$ per ha, however $\mathrm{T}_{4}$ produced an maximum income of Rs. $67,876.00$ per ha with a loss of Rs. 5,52,485.44 per ha. Minimum loss of Rs. 5,33,647.56 per ha was estimated in $\mathrm{T}_{3}$ and maximum loss of Rs. 5,69,497.94 per ha was estimated in $\mathrm{T}_{8}$ (Table 3). However, after due consideration of the trend in production of green leaf in $\mathrm{T}_{4}$, after expending an amount of
Rs. 6,20,361.44 per ha maximum income of Rs. $67,876.00$ per ha could be generated, which was closely followed by $\mathrm{T}_{5}$ (Table 3 ).

So, from the preceding results it could be observed that except $\mathrm{T}_{1}$ (control) and $\mathrm{T}_{2}$ (conventional) other treatments using organic fertilizers for commercial cultivation of organic tea in terai zone, $\mathrm{T}_{4}(\mathrm{VC}+\mathrm{Az}+\mathrm{P}+\mathrm{Pf}+\mathrm{As})$ was 
the most remunerative treatment combination, followed by $\mathrm{T}_{5}(\mathrm{VC}+\mathrm{Az}+\mathrm{V}+\mathrm{Pf}+\mathrm{As})$. Various fixed costs and variable costs evaluated. Treatment wise costs involved, yield of green leaf, income generated and profit or loss per ha, during two years were estimated. So, from the preceding results it could be observed that except $\mathrm{T}_{1}$ (control) and $\mathrm{T}_{2}$ (conventional), using inorganic fertilizers for commercial cultivation of organic tea in terai zone, $\mathrm{T}_{4}$ $(\mathrm{VC}+\mathrm{Az}+\mathrm{P}+\mathrm{Pf}+\mathrm{As})$ was the most remunerative treatment combination followed by $\mathrm{T}_{5}$ $(\mathrm{VC}+\mathrm{Az}+\mathrm{V}+\mathrm{Pf}+\mathrm{As})$.

Ipinmoroti et al., (2011) reported that in new planted garden, the readily availability of the organic fertilizer materials compared to NPK (25:5:5), their relatively cheaper procurement cost when used either sole or in combination with urea as organominerals and their better growth enhancement effects on tea plants suggests their inevitability for optimum tea production in Nigeria.

Evaluation of economics including fixed costs and variable costs among the organic treatments, $\mathrm{T}_{4}$ was observed to be the best with an income per ha for two years was Rs. 67,876 followed by $\mathrm{T}_{5}$ with Rs. 61,862 per ha. So, from the investigation, by observing the young tea plants only for two years, though it is premature to conclude, it was observed that $\mathrm{T}_{4}$ [vermicompost@1.0 kg + (Azotobacter + PSB + Fl. pseudomonas + Azospirillum) @ $5.0 \mathrm{~g}$ each] was the most remunerative treatment of organics for Terai zone of West Bengal.

\section{References}

Barthakur, B. K. (2004). Studies on vam symbiosis and rhizosphere microflora and effect of their interactions on growth and nutrition of tea plant. Tea Board pp. 11-15

Ipinmoroti, R.R., Iremiren, G.O., Olubamiwa, O., Fademi, A.O. and Aigbekaen, E.O. (2011). Effect of inorganic and organic based fertilizers on growth performance of tea and cost implications in Kusuku, Nigeria. Journal of Life Sciences. 5: 536-540.

Majumder A. B., Bera B. and Rajan, A. (2012). Tea Statistics: Global Scenario. International Journal of Tea Science. 8 (1): 121-124.

Mamaril, C. P., Rosales R. T. and Cabrora, M. S. (1986). Inorganic nitrogen fertilizer and green manure in lowland rice. Paper presented at the Insffer Planning Meeting Workshop in Hangzhon, China, September, 22-24.

Parmar, V.S. (2008). Cultivation and importance of organic tea in Darjeeling area. In improving productivity and quality of tea through traditional agricultural practices. Proceedings of National Seminar held during 15-16 Nov., 2008. pp. 36-45.

Phukan, I.K., Debnath, S. and Barthakur K. (2011). Biofertilizer and biopesticides in tea culture. Bioinfolet. 9(4B): 692-694.

Singh, A.K., Bisen, J. S, Bora, D.K., Kumar, R. and Bera, B. (2011). Comparative study of organic, inorganic and integrated plant nutrient supply on the yield of Darjeeling tea and soil health. Two Bud., 58:58-61.

Timsina, J. and Connor, D. J. (2001). Productivity and management of rice-wheat systems: Issues and challenges. Field Crops Research. 69: 93-132.

Van der Wal, S. (2008). Sustainability issues in the Tea Sector, A Comparative Analysis of Six Leading Countries, ISBN: 978-9071284-23-6, Stiching Onderzoek Multinationale Corporations, Sarphatistraat 30, 1018 Glamsterdam, pp: 108.

\section{How to cite this article:}

Vannam Yugandhar, G. Chandrashekhar and Bhattacharjee, H. 2018. Economics of Growing Tea Organically in the Initial Years in Terai Zone of West Bengal Condition. Int.J.Curr.Microbiol.App.Sci. 7(05): 387-391. doi: https://doi.org/10.20546/ijcmas.2018.705.050 